med økt ansvar for dårlige, hjemmeboende pasienter. Det er derfor også mange kommuner og fastleger som har nådd et «tipping point», og dette vil merkes i økende grad når en høy andel av de mest erfarne fastlegene går ut i pensjon de nærmeste årene.

\section{Oddmund Suhrke}

oddmund.suhrke@arendal.kommune.no

Oddmund Suhrke (f. 1953) er KAD (kommunale akutte døgnplasser) overlege i Arendal kommune.

Ingen oppgitte interessekonflikter.

\section{Litteratur}

1. Gjessing H. For mange pasienter er farlig. Tidsskr Nor Legeforen 2014; 134 1435

\section{RETTELSER}

Doktoravhandlinger

Universitetet i Bergen

Tidsskr Nor Legeforen 2014; 134: 1389

I Tidsskriftet nr. 14/2014 skal riktig tittel på doktoravhandlingen til Ingvild Bruun Mikalsen være: Asthma, atopy and lung function at 11 years of age after bronchiolitis in infancy.

Vi beklager feilen. Den er rettet på nett.

Selvmord og psykiske lidelser

Heidi Hjelmeland, Gudrun Dieserud, Kari Dyregrov, Birthe Loa Knizek. Mette Lyberg Rasmussen

Tidsskr Nor Legeforen 2014; 134: 1369-70

I Tidsskriftet nr. 14/2014 s. 1369, 3. spalte, 13. linje hadde en parentes falt ut. Riktig tekst er:

I Rasmussens studie av selvmord blant unge menn (18-30 år) (11) inngikk kun menn som ikke hadde vært i kontakt med psykisk helsevern, og som ikke tidligere hadde gjort selvmordsfors $ø$.

Vi beklager feilen. Den er rettet på nett.

\section{RETTELSE}

Er surrogatendepunkt i kliniske studier nyttige?

Cecilie Delphin Amdal, Kristin Bjordal

Tidsskr Nor Legeforen 2014; 134: 1128-9

I Tidsskriftet nr. 11/2014 s. 1129 er b og c i figur 2 blitt like. Riktig figur skal være:

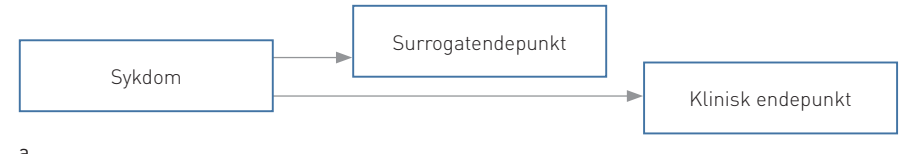

a.

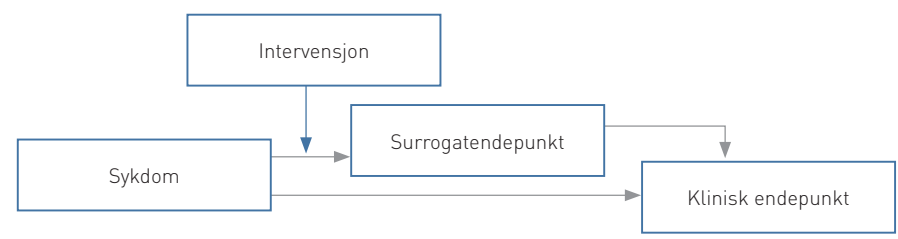

b.
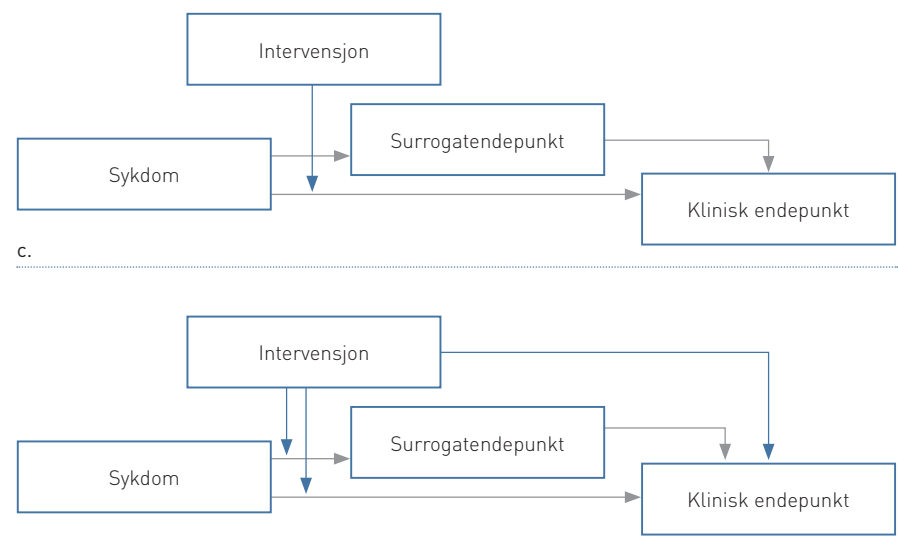

Vi beklager feilen. Den er rettet på nett. 